\title{
ANALISIS KINERJA KEUANGAN PADA KOPERASI SIMPAN PINJAM WIRA KARYA LAHAT KABUPATEN LAHAT
}

\author{
Oleh: Chandra Kunriawan ${ }^{1}$, Vera Desva Arianti \\ (UNIVERSITAS PGRI PALEMBANG) \\ ${ }^{1)}$ chandrakurniawan79@gmail.com
}

\begin{abstract}
Abstrak-Rumusan masalah dalam Penelitian ini yaitu Bagaimana kinerja keuangan pada koperasi simpan pinjam wira karya lahat kabupaten lahat?. Tujuan dalam penelitian ini adalah untuk mengetahui Kinerja Keuangan pada Koperasi Simpan Pinjam Wira Karya Lahat.Variabel dalam penelitian ini adalah variabel tunggal yaitu Analisis Kinerja Keuangan pada Koperasi Simpan Pinjam Wira Karya Lahat Kabupaten Lahat. Metode penelitian yang digunakan adalah metode deskriptif. Teknik pengumpulan data yang digunakan adalah yaitu dokumentasi dan wawancara. Teknik analisis data yang digunakan adalah aspek permodalan, aspek kualitas aktiva produktif, aspek manajemen, aspek efesiensi dan aspek Likuiditas.Berdasarkan hasil penelitian diketahui bahwa pada aspek permodalan Koperasi Simpan Pinjam Wira Karya Lahat pada tahun 2015-2017 memperoleh skor 47 dengan Predikat dalam pengawasan khusus atau tidak sehat, aspek kualitas aktiva produktif memperoleh skor 16,25 dengan predikat dalam pengawasan atau kurang sehat. Aspek manajemen memperoleh skor 13,75 dengan predikat sangat baik atau sangat sehat. Aspek efesiensi memperoleh skor 2,00 dalam predikat dalam pengawasan khusus atau tidak baik dan Aspek Likuiditas memperoleh skor 3,75 dalam predikat tidak baik atau tidak sehat. Maka dapat disimpulkan perolehan skor untuk menilai kinerja keuangan pada Koperasi Simpan Pinjam Wira Karya Lahat pada tahun 2015-2017 tidak baik atau tidak sehat.
\end{abstract}

Kata Kunci: Kinerja Keuangan, Aspek Permodalan, Aspek Kualitas Aktiva Produktif, Aspek Manajemen, Aspek Efesiensi dan Aspek Likuiditas

\begin{abstract}
Abstrack-The formulation of the problem in this study is how the financial performance of the savings and loan cooperative in the district work is bad? The purpose of this study was to determine the financial performance of the Wira Karya Lahat Savings and Loans Cooperative. The variables in this study were single variables, namely the Financial Performance Analysis on the Savings and Loans Cooperative of Lira Karya Lahat Regency. The method used is descriptive method. Data collection techniques used are documentation and interviews. Data analysis techniques used are capital aspects, productive asset quality aspects, management aspects, efficiency aspects and liquidity aspects. Based on the results of the study it is known that the capital aspect of Wira Karya Lahat Savings and Loans Cooperative in 2015-2017 obtained a score of 47 with a predicate under special supervision. or unhealthy, the quality aspect of earning assets gets a score
\end{abstract}


of 16.25 with a predicate in supervision or unhealthy. Management aspects get a score of 13.75 with a very good or very healthy predicate. The efficiency aspect gets a score of 2.00 in the predicate in special or bad supervision and the Liquidity Aspect gets a score of 3.75 in the predicate of not good or unhealthy. So it can be concluded that the acquisition of scores to assess the financial performance of the Wira Karya Lahat Savings and Loans Cooperative in 20152017 is not good or unhealthy

Keywords: Financial Performance, Capital Aspects, Aspects of Earning Assets Quality, Management Aspects, Efficiency Aspects and Aspects of Liquidity

\section{PENDAHULUAN}

\section{Latar Belakang}

Koperasi adalah suatu bentuk kerjasama dalam lapangan perekonomian, yang lahir sebagai reaksi terhadap sistem liberalisme ekonomi pada abad ke-19. Di Indonesia koperasi merupakan sarana pembangunan perekonomian Nasional yang bertujuan untuk mewujudkan kedaulatan politik dan ekonomi Indonesia melalui pengelolaan sumber daya ekonomi dalam suatu iklim pengembangan dan pemberdayaan koperasi yang memiliki peran strategis dalam tata ekonomi Nasional berdasarkan asas kekeluargaan dan demokrasi ekonomi dalam rangka menciptakan masyarakat yang maju, adil, dan makmur berlandaskan Pancasila dan Undang-Undang Dasar Negara Republik Indonesia Tahun 1945.

Pengembangan usaha di koperasi diarahkan agar koperasi mampu mengembangkan prakarsa dan swakarsa. Koperasi diharapkan menjadi pusat pelayanan kegiatan perekonomian di daerah dan dapat memegang peranan utama dalam kegiatan perekonomian, khususnya disektor pertanian, penyaluran kebutuhan pokok masyarakat, jasa, industri kecil, kerajinan rakyat, dan bidang lain sesuai kemampuan serta keadaan daerah setempat.

Koperasi dikenal sebagai suatu bentuk perusahaan yang dimiliki anggotanya. Dengan adanya koperasi, perekonomian di Indonesia berkembang semakin baik, sehingga dapat memajukan usaha bersama dan mensejahterakan kehidupan anggotanya.

Koperasi di Indonesia terbentuk berdasarkan Undangundang yang pada saat ini diterangkan dalam undang-undang No 17 tahun 2012 tentang perkoperasian. Berdasarkan undangundang tersebut Koperasi adalah badan hukum yang didirikan oleh orang perseorangan atau badan hukum Koperasi, dengan pemisahan kekayaan para anggotanya sebagai modal untuk menjalankan usaha, yang memenuhi aspirasi dan kebutuhan bersama dibidang ekonomi, sosial, dan budaya sesuai dengan nilai dan prinsip koperasi. 
Salah satu bentuk koperasi berdasarkan undang-undang No 17 tahun 2012 adalah Koperasi Simpan Pinjam. Koperasi Wira Karya ini termasuk koperasi Simpan Pinjam, setiap tahun harus membuat laporan tahunan yang berisi Laporan keuangan.

Keberhasilan koperasi dalam mengelolah keberhasilan manajemen dalam mengolah koperasi dapat dilihat dari kinerja keuangan dari koperasi tersebut. Oleh karena itu, penilaian terhadap analisis atau kinerja keuangan suatu koperasi sangat diperlukan.

$\begin{array}{ccc}\begin{array}{c}\text { Laporan } \\ \text { dikeluarkan }\end{array} & \text { koperasi } & \text { yang } \\ \text { harus }\end{array}$
memberikan informasi posisi dan kondisi keuangan koperasi akan tetapi laporan tersebut perlu di analisa lebih lanjut dengan alat analisa keuangan yang ada untuk mendapatkan informasi yang lebih berguna dan lebih spesifik dalam menjelaskan posisi dan kondisi keuangan. Salah satu alat untuk mengukur kinerja keuangan koperasi yaitu dengan menggunakan teknik analisis rasio keuangan. Analisis rasio keuangan merupakan alat analisa yang digunakan untuk melihat kondisi keuangan koperasi dan dapat menjelaskan atau memberi gambaran kepada penganalisa tentang baik dan buruknya keadaan atau posisi keuangan dari suatu periode ke periode berikutnya. Dalam menganalisis rasio keuangan diperlukan data keuangan yang sah dan akan dipakai sebagai dasar pengukuran.

Cara untuk menilai Kinerja Kuangan Koperasi adalah dengan melihat dari : Permodalan, Kualitas aktiva produktif, Manajemen, Efisiensi, Likuiditas, Kemandirian Pertumbuhan dan Jatidiri Koperasi. Kinerja keuangan koperasi dalam penyajian ini untuk melihat ukuran koperasi berprestasi yang dituangkan dalam Peraturan Menteri Negara Koperasi dan UKM Republik Indonesia Nomor 06/PER/DEP.6/IV/2016 tentang pedoman penilaian kesehatan koperasi simpan pinjam dan unit simpan pinjam koperasi..

Salah satu Koperasi yang ada di Kabupaten Lahat adalah Koperasi Simpan Pinjam Wira Karya. Anggota koperasi Wira Karya terdiri dari pegawai PNS, pegawai swasta dan anggota masyarakat. Koperasi Wira Karya bergerak dalam usaha simpan pinjam dari anggotanya, tujuannya agar peminjamnya dapat dilakukan dengan cepat dan mudah dibandingkan dengan Bank. Koperasi simpan pinjam mempunyai usaha meminjamkan dana dan menerima simpanan dana dari anggota atau masyarakat sehingga identik dengan bank yang usaha pokoknya adalah jasa dalam keuangan.

Pada umumnya untuk masyarakat di Kabupaten Lahat banyak tergantung pada harga karet, kopi dan sedikit Sawit. Bila harga 
komoditi naik maka penghasilan naik, bila komoditi mengalami penurunan maka pendapatan menurun yang dapat mempengaruhi angsuran pinjaman dari anggota.

Sebagai koperasi simpan pinjam Wira Karya usahanya adalah meminjamkan dana dan menerima dana dari anggota atau pihak lainnya. Koperasi ini dengan sendirinya harus mempunyai modal atau dana untuk dipinjamkan yang bersumber dari iuran anggota/simpanan anggota dan iuran dari lembaga lainnya. Walaupun tujuan utama koperasi meningkatkan kesejahteraan anggota, namun koperasi harus memperoleh laba agar koperasi dapat hidup terus namun bunga dana yang dipinjamkan kepada anggota/peminjam dalam hal ini haruslah wajar dengan prosedur yang mudah. Laba tersebut dapat menjadi salah satu sumber dana/modal koperasi dengan cara membentuk cadangan dan menyisihkan sebagian dari laba. Penghasilan dari koperasi simpan pinjam adalah bunga atau balas jasa dari dana yang dipinjam oleh anggotanya atau pihak lain.

Berdasarkan wawancara awal yang diperoleh dari Kepala koperasi yaitu bapak Suhardi pada tanggal 4 April 2018 di Kantor Koperasi itu sendiri, bahwa koperasi Simpan Pinjam Wira Karya Lahat Kabupaten Lahat belum pernah dilakukan perhitungan kinerja keuangan, setiap tahunnya pengurus koperasi hanya membuat laporan pertanggung jawaban tahunan yang berisikan Neraca dan Sisa hasil usaha saja. Sebernarnya perlu untuk melakukan analisis keuangan berupa rasio keuangan agar dapat melihat kinerja keuangan, apakah koperasi tersebut sehat atau tidak sehat.

Dari uraian di atas, maka peneliti tertarik untuk mengadakan penelitian pada koperasi simpan pinjam Wira Karya Lahat dengan judul "Analisis Kinerja Keuangan pada Koperasi Simpan Pinjam Wira Karya Lahat Kabupaten Lahat”.

\section{Rumusan Masalah}

Berdasarkan uraian latar belakang di atas, maka penulis dapat merumuskan masalahnya yaitu "Bagaimana Kinerja Keuangan pada Koperasi Simpan Pinjam Wira Karya Lahat Kabupaten Lahat dilihat dari rasio keuangan?"

\section{Tujuan Penelitian}

Tujuan dari penelitian ini merupakan untuk mengetahui kinerja keuangan yang diukur dengan rasio laporan keuangan koperasi simpan pinjam Wira Karya Lahat.

\section{Manfaat Penelitian}

Penelitian ini diharapkan dapat bermanfaat bagi semua pihak yaitu :

a. Bagi Koperasi Wira Karya

Sebagai acuan untuk pedoman dalam koperasi dan juga sebagai bahan masukan dalam mengelola 
keuangannya di masa yang akan datang.

b. Bagi Peneliti Selanjutnya

Diharapkan dapat menjadi salah satu bahan acuan untuk melakukan penelitian serupa yang jauh lebih baik lagi.

c. Bagi Perguruan Tinggi

Untuk menambah pengetahuan, informasi sekaligus sebagai bahan acuan untuk referensi dalam penelitian yang serupa menggunakan laporan keuangan

\section{Landasan Teori}

\section{Pengertian Kinerja}

Menurut Wibowo, (2007:2)

"Kinerja merupakan tentang melakukan pekerjaan dan hasil yang dicapai dari pekerjaan tersebut".

\section{Pengertian Kinerja Keuangan}

Menurut Sucipto dalam Saraswati (2013:4), "Kinerja keuangan adalah penentuan ukuranukuran tertentu yang dapat mengukur keberhasilan suatu perusahaan dalam menghasilkan laba".

\section{Faktor-Faktor Kinerja Keuangan Koperasi}

Menurut Monica (2017)

Faktor-faktor kinerja keuangan koperasi adalah banyak koperasi yang tidak memiliki komitmen, dan tujuan yang jelas ketika dibangun. Jadi koperasi itu dibangun hanya untuk kepentingan pengurusnya saja.

\section{Laporan Keuangan}

Menurut Munawir dalam Fahmi (2012:22) mengatakan "Laporan keuangan merupakan alat yang sangat penting untuk memperoleh informasi sehubungan dengan posisi keuangan dan hasilhasil yang telah dicapai oleh perusahaan yang bersangkutan.

Laporan Keuangan dan Pengaruhnya bagi Perusahaan

Pada setiap perusahaan bagian keuangan memegang peran penting dalam menentukan arah perencanaan perusahaan. Ini seperti dikatakan oleh Napa J. Awat dalam Fahmi, (2012:23) bahwa “ Berfungsinya bagian keuangan merupakan prasyarat bagi kelancaran pelaksanaan kegiatan pada bagianbagian lainnya". Dengan berfungsinya secara baik bagian keuangan membuat kinerja keuangan yang dilihat dari laporan keuangan perusahaan akan tersaji dengan baik. Sehingga pihak-pihak yang membutuhkan akan dapat memperoleh laporan keuangan tersebut dan membantunya dalam proses pengambilan keputusan sesuai dengan yang diharapkan. Dalam analisis informasi keuangan, setiap aktivitas bisnis harus dianalisis secara mendalam baik manajemen maupun oleh pihak-pihak yang berkepentingan dengan perusahaan yang bersangkutan. Dari definisi diatas dapat dipahami bahwa manajemen menyajikan laporan keuangan dan pihak luar perusahaan 
memanfaatkan informasi tersebut untuk membantu membuat keputusan.

Sebuah laporan keuangan pada umumnya terdiri dari :

1. Neraca

2. Laporan laba rugi

3. Laporan perubahan modal

4. Laporan arus kas

5. Catatan atas laporan keuangan

\section{Tujuan Laporan Keuangan}

Menurut Fahmi (2012:26)

"tujuan laporan keuangan adalah memberikan informasi kepada pihak yang membutuhkan tentang kondisi suatu perusahaan dari sudut angkaangka dalam satuan moneter.।

\section{Keterbatasan Laporan Keuangan}

Setiap laporan keuangan yang disusun pasti memiliki keterbatasan tertentu menurut Kasmir (2008:16) adalah :

1. Pembuatan laporan keuangan disusun berdasarkan sejarah (historis), dimana data-data yang diambil dari data masa lalu.

2. Laporan keuangan dibuat umum, artinya untuk semua orang bukan hanya untuk pihak tertentu saja.

3. Proses penyusunan tidak terlepas dari taksiran-taksiran dan pertimbangan tertentu.

4. Laporan keuangan bersifat konservatif dalam menghadapi situasi ketidakpastian.

5. Laporan keuangan selalu berpegangan teguh kepada sudut pandang ekonomi dalam memandang peristiwa-peristiwa yang terjadi bukan sifat formalnya.

\section{Komponen-Komponen Laporan Keuangan}

Komponen-komponen laporan keuangan menurut Munawir (2010:13-26) terdiri dari :

1. Laporan Laba-rugi

2. Laporan Perubahan Ekuitas

3. Neraca

4. Laporan Arus Kas

\section{Koperasi}

Menurut Soeriaatmadja dalam ( Hendrojogi 2015:21-22) "Koperasi adalah suatu perkumpulan dari orang-orang yang atas dasar persamaan derajat sebagai manusia, dengan tidak memandang haluan agama dan politik secara sukarela masuk, untuk sekedar memenuhi kebutuhan bersama yang bersifat kebendaan atas tanggungan bersama."

\section{Landasan, Asas dan Tujuan Koperasi}

1. Landasan Koperasi

Menurut undang-undang Perkoperasian tahun 2012 pasal 2 "Koperasi berlandaskan Pancasila dan Undang-Undang Dasar 1945 serta berdasarkan atas asas kekeluargaan.

2. Asas koperasi

Menurut Undang-Undang Republik Indonesia Nomor 17 
tahun 2012 pasal 3, koperasi berdasar atas asas kekeluargaan.

3. Tujuan Koperasi

Berdasarkan pasal 4 Undangundang Perkoperasian tahun 2012 telah dijelaskan bahwa koperasi bertujuan meningkatkan kesejahteraan anggota pada khususnya dan masyarakat pada umumnya, sekaligus sebagai bagian yang tidak terpisahkan dari tatanan perekonomian nasional yang demokratis dan berkeadilan.

\section{Modal Koperasi}

Modal Koperasi menurut Undang-Undang Perkoperasian Pasal 66, meliputi:

1. Modal koperasi terdiri dari setoran pokok dan sertifikat modal koperasi sebagai modal awal.

2. Selain modal sebagaimana di maksud pada ayat (1) modal koperasi dapat berasal dari :
a. Hibah
b. Modal Penyertaan
c. Modal Pinjaman yang berasal dari:

1. Anggota

2. Koperasi lainnya dan anggotanya

3. Bank dan lembaga keuangan lainnya

4. Penerbitan obliagasi dan surat hutang lainnya

5. Sumber lain yang sah

d. Sumber lain yang sah tidak bertentangan dengan anggaran dasar dan ketentuan peraturan

perundang-undangan.

\section{Prinsip-Prinsip Koperasi}

Prinsip-prinsip koperasi adalah pedoman bagi koperasi-koperasi dalam melaksanakan nilai-nilai koperasi dalam praktik. Sebagaimana dinyatakan dalam pasal 6 UndangUndang No 17 tahun 2012 prinsipprinsip koperasi sebagai berikut :

1. Keanggotaan bersifat sukarela dan terbuka

2. Pengolahan dilakukan secara demokratis

3. Pembagian sisa hasil usaha dilakukan secara adil dan sebanding dengan besarnya jasa masing-masing anggota

4. Pemberian balas jasa yang terbatas pada modal

5. Kemandirian

\section{Jenis-Jenis Koperasi}

Berbagai jenis koperasi lahir seirama dengan aneka jenis usaha untuk memperbaiki kehidupan. Dalam Undang-undang No 17 Tahun 2012 tentang pengkoperasian jenisjenis koperasi yaitu : 1. Koperasi Konsumen, 2. Koperasi produsen, 3. Koperasi jasa, dan 4. Koperasi Simpan Pinjam

\section{Tujuan Penilaian Kinerja Keuangan Koperasi}

Pedoman penilaian kesehatan koperasi simpan pinjam berdasarkan Peraturan Deputi Bidang Pengawasan Kementerian Koperasi 
dan Usaha Kecil dan Menengah Republik Indonesia Nomor 06/Per/Dep.6/IV/2016 bertujuaan untuk memberikan pedoman dalam pelaksanaan penilaian kesehatan Koperasi.

\section{Sasaran Penilaian Kinerja Keuangan Koperasi}

Sasaran penilaian kesehatan usaha koperasi berdasarkan Peraturan Deputi Bidang Pengawasan Kementerian Koperasi dan Usaha Kecil dan Menengah Republik Indonesia Nomor 06/Per/Dep.6/IV/2016 adalah sebagai berikut :

a. Terwujudkan pengelolaan Koperasi yang sehat dan sesuai ketentuan peraturan perundangundangan.

b. Terwujudnya pelayanan prima kepada penggunaan jasa koperasi.

c. Meningkatkan citra dan kredibilitas kegiatan usaha simpan pinjam oleh koperasi sebagai lembaga keuangan yang mampu mengelola kegiatan usaha simpan pinjam sesuai dengan peraturan perundang-undangan.

d. Terjaminnya aset kegiatan usaha simpan pinjam oleh koperasi sesuai dengan peraturan perundang-undangan.

e. Meningkatnya transparansi dan akuntabilitas pengelolaan kegiatan usaha simpan pinjam oleh koperasi. f. Meningkatnya manfaat ekonomi anggota dalam kegiatan usaha simpan pinjam oleh koperasi.

\section{Landasan Penilaian Kinerja Keuangan Koperasi}

Landasan kerja penilaian kesehatan koperasi berdasarkan Peraturan Deputi Bidang Pengawasan Kementerian Koperasi dan Usaha Kecil dan Menengah Republik Indonesia Nomor 06/Per/Dep.6/IV/2016 adalah sebagai berikut :

1. Koperasi menyelenggarakan kegiatan usahanya berdasarkan peraturan perundang-undangan.

2. Koperasi dilakukan untuk memenuhi kebutuhan keuangan anggota secara bersama.

3. Anggota koperasi berada dalam satu kesatuan sistem kerja koperasi, yang diatur dalam anggaran dasar dan anggaran rumah tangga koperasi.

4. Koperasi wajib memberikan manfaat yang lebih besar kepada anggotanya.

\section{Metodologi Penelitian}

\section{Metode Penelitian}

Menurut Nazir, (2011:33) "Metode penelitian merupakan memandu peneliti tentang uruturutan bagaimana penelitian dilakukan". Metode penelitian yang digunakan peneliti adalah deskriptif. "Metode deskriptif adalah penelitian untuk membuat gambaran mengenai situasi atau kejadian, sehingga 
metode ini berkehendak mengadakan akumulasi data dasar belaka" (Nazir, 2011:43).

\section{Teknik Pengumpulan Data}

Dalam suatu penelitian terjadi proses pengumpulan data, yang bertujuan untuk memperoleh informasi yang selengkaplengkapnya untuk menunjang penelitian. Proses pengumpulan data tersebut dapat dilakukan dengan teknik-teknik tertentu. Teknik yang digunakan dalam proses pengumpulan data tergantung pada sifat dan karakteristik penelitian yang hendak dilakukan oleh peneliti. Teknik pengumpulan data yang digunakan dalam penelitian ini, antara lain :

\section{a) Dokumentasi}

"Dokumentasi adalah mencari data mengenai hal-hal atau variabel zyang berupa catatan, transkip, buku, surat kabar, majalah, prastasi, notulen rapat, lengger, agenda dan sebagainya" (Arikunto, 2014:274). Sedangkan menurut Sugiyono, (2013:422) mendeskripsikan dokumentasi berasal dari kata dokumen yang mempunyai arti yaitu "Dokumen merupakan catatan peristiwa yang sudah berlaku bisa berbentuk tulisan, gambar, karyakarya monumental dari seseorang. Dokumen yang berbentuk tulisan misalnya gambar, atau karya-karya monumental dari seseorang, sejarah kehidupan, biografi, peraturan, kebijakan". Dokumen yang berbentuk gambar misalnya foto, sketsa dan lain-lainnya. Dokumen yang berbentuk karya misalnya karya seni, yang dapat berupa gambar, patung ataupun dalam bentuk film. Dalam teknik ini sumber-sumber yang digunakan adalah buku-buku laporan keuangan koperasi, buku neraca, rugi laba dan bukti lainnya yang berhubungan.

b) Wawancara (interview)

Menurut Nazir (2011:170-171)

“ Wawancara adalah proses memperoleh keterangan untuk tujuan penelitian dengan cara tanya jawab, sambil bertatap muka antara si penanya atau pewawancara dengan si penjawab atau responden dengan menggunakan alat yang dinamakan Interview Guid (paduan wawancara). Teknik ini digunakan untuk mengetahui keadaan umum perusahaan mengenai laporan keuangan koperasi. Untuk mengetahui keadaan umum koperasi perlu diajukan beberapa pertanyaan yang menyangkut dengan masalah kinerja keuangan dan teknik dalam melakukan analisis data supaya bisa melihat kinerja keuangan koperasi tersebut yaitu dengan melihat Permodalan, kualitas aktiva produktif, manajemen, efisiensi, dan likuiditas. Yang akan diajukan pertanyaan ini yaitu kepala koperasi itu sendiri serta pegawai-pegawai yang bersangkutan. 


\section{Teknik Analisis Data}

Analisis data adalah proses mencari dan menyusun secara sistematis data yang diperoleh dari hasil wawancara, catatan lapangan dan bahan-bahan lain, sehingga dapat dengan mudah dipahami dan temuannya dapat diinformasikan orang lain" (Sugiyono, 2013:88).

Teknik analisis data yang digunakan adalah deskriptif yaitu menggambarkan keadaan yang berlaku tanpa bermaksud mengadakan penelitian. Dalam penelitian ini teknik yang diteliti adalah rasio keuangan berdasarkan Peraturan Menteri Negara Koperasi dan UKM Republik Indonesia Nomor 06/Per/Dep.6/IV/2016 tentang pedoman penilaian kesehatan koperasi simpan pinjam dan unit simpan pinjam koperasi.

\section{Permodalan}

1. Rasio Modal Sendiri terhadap Total Aset

Rumus yaang digunakan yaitu: $\frac{\text { modal sendiri }}{\text { total aset }} \times 100 \%$

2. Rasio Modal Sendiri terhadap Pinjaman diberikan yang berisiko Rumus yang digunakan yaitu: $\frac{\text { modal sendiri }}{\text { pinjaman diberikan berisiko }} \times 100 \%$

3. Rasio Kecukupan Modal Sendiri Rumus yang digunakan yaitu: $\frac{\text { modal sendiri tertimbang }}{\text { ATMR }} \times 100 \%$

\section{Kualitas Aktiva Produktif}

1. Rasio Volume Pinjaman pada Anggota terhadap volume pinjaman Diberikan

Rumus yang digunakan yaitu: $\frac{\text { volume pinjaman pada anggota }}{\text { volume pinjaman }} \times 100 \%$

2. Rasio Risiko Pinjaman Bermasalah Terhadap Pinjaman Diberikan

Rumus yang digunakan yaitu: $\frac{\text { pinjaman bermasalah }}{\text { pinjaman yang diberikan }} \times 100 \%$

3. Rasio Cadangan Risiko Terhadap Pinjaman Bermasalah Rumus yang digunakan yaitu: $\frac{\text { cadangan risiko }}{\text { pinjaman bermasalah }} \times 100 \%$

4. Rasio Pinjaman yang Berisiko terhadap Pinajaman yang diberikan

Rumus yang digunakan yaitu: $\frac{\text { pinjaman yang berisiko }}{\text { pinjaman yang diberikan }} \times 100 \%$

\section{Penilaian Manajemen}

1. Manajemen Umum

2. Manajemen Kelembagaan

3. Manajemen Permodalan

4. Manajemen Aktiva

5. Manajemen Likuiditas

\section{Efisiensi}

1. Rasio Beban Operasi Anggota Terhadap Partisipasi Bruto Rumus yang digunakan yaitu: $\frac{\text { beban operasi anggota }}{\text { Partisipasi Bruto }} \times 100 \%$

2. Rasio Beban Usaha Terhadap SHU Kotor

Rumus yang digunakan yaitu: $\frac{\text { beban usaha }}{\text { SHU kotor }} \times 100 \%$

3. Rasio Efisiensi pelayanan 
Rumus yang digunakan yaitu:

$\frac{\text { biaya karyawan }}{\text { volume pinjaman }} \times 100 \%$

\section{Likuiditas}

1. Rasio Kas

Rumus yang digunakan yaitu:

$$
\frac{\text { kas +bank }}{\text { kewajiban lancar }} \times 100 \%
$$

2. Rasio Pinjaman yang Diberikan terhadap Dana yang diterima

Rumus yang digunakan yaitu:

$\frac{\text { pinjaman yang diberikan }}{\text { dana yang diterima }} \times 100 \%$

Analisis Rasio keuangan diatas dilakukan tiap tahun dan membandingkan selama 3 tahun dari 2015 sampai tahun 2017. Untuk menilai kinerja keuangan koperasi telah menghasilkan sehat tidaknya koperasi tersebut digunakan ukuran kesehatan koperasi pada Peraturan Menteri Negara Koperasi dan UKM Republik Indonesia Nomor 06/Per/Dep.6/IV/2016 tentang pedoman penilaian kesehatan koperasi simpan pinjam dan unit simpan pinjam koperasi.

Untuk mengetahui kinerja keuangan koperasi dalam penelitian ini digunakan ukuran kesehatan koperasi dalam Peraturan Deputi Bidang Pengawasan Kementerian Koperasi dan Usaha Kecil dan Menengah Republik Indonesia Nomor 06/Per/Dep.6/IV/2016 tentang Pedoman Penilaian Kesehatan Koperasi Simpan Pinjam dan Unit Simpan Pinjam.

Berdasarkan hasil perhitungan penilaian terhadap lima aspek sebagaimana dimaksud pada angka 1 sampai 5 aspek, diperoleh secara keseluruhan. Skor yang dimaksud dipergunakan untuk menetapkan predikat tingkat kesehatan Koperasi, yang dibagi dalam 4 (empat) kategori.

Penetapan Predikat Tingkat Kesehatan KSP

\begin{tabular}{|c|l|}
\hline Skor & \multicolumn{1}{|c|}{ Predikat } \\
\hline $80.00 \leq \mathrm{x} \leq 100$ & Sehat \\
\hline $66.00 \leq \mathrm{x}<80.00$ & Cukup Sehat \\
\hline $51.00 \leq \mathrm{x}<66.00$ & Dalam Pengawasan \\
\hline$<51$ & Dalam Pengawasan Khusus \\
\hline Sumber: & Peraturan Menteri Negara Koperasi dan \\
& Usaha Kecil Menengah Republik Indonesia \\
& tahun 2016
\end{tabular}

\section{PEMBAHASAN}

Hasil Penelitian Dikaitkan dengan Kajian Teori

\section{a. Penilaian Aspek Permodalan} KSP Wira Karya Lahat

Berdasarkan analisis yang telah dilakukan, menunjukan bahwa pada aspek permodalan KSP Wira Karya Lahat Tahun 2015-2017, skor kesehatan koperasi mengalami penurunan yang berturut-turut. Tahun 2015 sebesar 10,20 menurun menjadi 7,80 tahun 2016 dan menurun lagi tahun 2017 mencapai 7,05 . Berdasarkan hal diatas peneliti beranggapan kinerja keuangan koperasi dari aspek permodalan mendapatkan predikat tidak sehat. Hal tersebut menurut peneliti karena kesebandingan untuk dana yang tersedia dengan dana yang dipinjamkan harus sesuai, yang berarti bila modal besar yang dipinjamkan harus besar atau sebaliknya. 
b. Aspek Penilaian Kualitas Aktiva Produktif KSP Wira Karya Lahat

Penilaian aspek kualitas aktiva produktif KSP Wira Karya Lahat tiga tahun terakhir 2015-2017 ternyata sama dengan aspek permodalan, yaitu mengalami penurunan. Skor total kesehatan koperasi tahun 2015 19,75 menjadi 16,25 tahun 2017 yang berada pada predikat dalam pengawasan, yang berarti kinerja keuangan dari aspek ini kurang sehat. Hal ini menurut peneliti disebabkan menurunnya rasio pinjaman yang berisiko terhadap pinjaman yang diberikan.

\section{c. Aspek Penilaian Manajemen KSP Wira Karya Lahat}

Penilaian aspek manajemen KSP Wira Karya dilakukan dengan cara melakukan perhitungan dan penyekoran terhadap lima komponen yaitu manajemen umum, kelembagaan, manajemen permodalan, manajemen aktiva dan manajemen likuiditas. Dari hasil perhitungan dan penyekoran yang telah dilakukan aspek manajemen KSP Wira Karya Lahat tahun 20152017 pada tahun ketahun stabil. Pada tahun 2015 skor total $92 \%$ berada pada predikat sehat, pada tahun 2016 skor total skor $92 \%$ berada pada sehat, sedangkan pada tahun 2017 skor total adalah $92 \%$ berada pada predikat sehat dan artinya aspek Manajemen koperasi sehat. Maka dari pernyataan peneliti bahwa kinerja keuangan koperasi dari aspek Manajemen tahun terakhir adalah sehat.

\section{d. Aspek Penilaian Efesiensi KSP Wira Karya Lahat}

Penilaian aspek efesiensi KSP Wira Karya Lahat tahun 2015-2016 mengalami peningkatan. Skor total kesehatan koperasi tahun 2015 1,00 meningkat menjadi 2,00 tahun 2017 meningkatnya total skor menurut peniliti yaitu pada rasio efesiensi pelayanan. yang berada pada predikat dalam pengawasan khusus, yang berarti kinerja keuangan dari aspek ini tidak sehat.

\section{e. Aspek Penilaian Likuiditas KSP Wira Karya Lahat}

Penilaian aspek likuiditas usaha simpan pinjam KSP Wira Karya Lahat tiga tahun terakhir tahun 2015-2017 ternyata sama atau seimbang dari tahun- tahun sebelumnya, karena setiap rasio tidak mengalami kenaikan atau tidak mengalami perubahan, jadi koperasi berada pada predikat dalam pengawasan khusus yang artinya kinerja keuangan koperasi dari aspek ini tidak sehat.

\section{Hasil Penelitian Dikaitkan dengan Kajian Penelitian Relevan}

Hasil penelitian yang didapat yaitu bahwa koperasi simpan pinjam wira karya belum pernah melakukan analisis kinerja keuangan. Koperasi Simpan Pinjam Wira Karya Lahat 
setiap tahunnya pengurus koperasi hanya membuat laporan pertanggung jawaban tahunan yang berisikan Neraca dan Sisa hasil usaha saja.

Penelitian yang peneliti lakukan berbeda hasil dengan penelitian Anita Aprilia 2014 "Analisis Laporan Keuangan Untuk Mengukur Kinerja Keuangan pada Koperasi Dhaya Harta Jombang". Hasil penelitian rasio likuiditas mengalami peningkatan dari tahun 2007 sampai 2011, rasio solvabilitas mengalami penurunan, berdasarkan rasio aktivitas mengalami penurunan dari tahun 2007 sampai 2011 dan berdasarkan rasio profitabilitas cukup baik.

Penelitian yang dilakukan oleh Dwi Putra Darmawan yang berjudul "Analisis Kinerja Keuangan pada Koperasi Serba Usaha di Kabupaten Buleleng". Dengan hasil penelitian sesuai dengan KEP.MEN.NEG tentang tingkat efesiensi rata-rata gabungan current rasio sebesar $186,3 \%$ debt to asset rasio sebesar $67,10 \%$ dan debt to equity ratio $466,16 \%$ analisis rata-rata gabungan receivable turn over sebesar 1,11 kali, rata-rata gabungan cash turn over sebesar 23,34 kali

Selanjutnya penelitian yang berjudul "Analisis Kinerja Keuangan Koperasi Serba Usaha di Kecamatan Buleleng Tahun 2013”. Hasil penelitian rasio struktur modal sebagian besar memiliki rasio diatas $125 \%$ yang artinya berada dalam kategori baik. Hasil perhitungan rasio likuiditas memiliki rasio yang terletak dalam rentang 125\%-149\% yang berada dalam kategori cukup baik, rasio solvabilitas berada dalam rentang $120 \%-134 \%$ atau dalam kategori baik dan berdasarkan rasio profitabilitas berada dalam rentang 8\%-11\% berada dalam kategori baik.

Sedangkan hasil penelitian yang dilakukan oleh peneliti bahwa peraturan yang dipakai berbeda dengan peneliti-peneliti sebelumnya maka rumus yang digunakanpun berbeda peraturan yang digunakan peneliti yaitu Peraturan Deputi Bidang Pengawasan Kementerian Koperasi dan Usaha Kecil dan Menengah Republik Indonesia Nomor 06/Per/Dep.6/IV/2016 tentang Pedoman Penilaian Kesehatan Koperasi Simpan Pinjam dan Unit Simpan Pinjam Koperasi. Hasil penelitian pada aspek permodalan koperasi simpan pinjam wira karya lahat tidak sehat, pada aspek kualitas aktiva produktif kurang sehat, pada aspek manajemen sangat sehat, aspek efesiensi tidak sehat atau dalam pengwasan khusus dan pada aspek likuiditas juga kurang baik atau tidak sehat.

\section{KESIMPULAN}

Berdasarkan hasil penelitian untuk mengetahui kinerja keuangan dari Koperasi Simpan Pinjam Wira Karya Lahat dari laporan keuangan (Neraca dan Laba Rugi) tahun 20152017 maka dapat disimpulkan bahwa: 
1. Aspek Permodalan koperasi dari tahun 2015-2017 mengalami penurunan. Pada tahun 2015 total skor 10,20 menurun menjadi 7,05 tahun 2017 maka dapat diartikan kinerja keuangan koperasi mendapatkan predikat tidak sehat. Berdampak pada pemodalan yang ada pada koperasi untuk memberikan pinjaman kepada anggotanya.

2. Aspek Kualitas Aktiva Produktif Koperasi dari tahun 2015-2017. Juga mengalami penurunan. Pada tahun 2015 total skor 19,75 menurun menjadi 16,25 pada tahun 2017 maka diartikan kinerja keuangan koperasi mendapatkan predikat kurang sehat. Akan berdampak pada kualitas pelayanan dari pengurus koperasi kepada anggota koperasi.

3. Aspek Manajemen Koperasi dari tahun 2015-2016 tidak mengalami perubahan atau sama. Pada tahun 2015-2017 mendapatkan total skor 13,75 maka kinerja keuangan koperasi mendapat predikat sehat.

4. Aspek Efesiensi Koperasi dari tahun 2015-2017 mengalami peningkatan. Pada tahun 2015 mendapatkan total skor 1,00 meningkat menjadi 2,00 pada tahun 2017 maka dapat diartikan kinerja keuangan koperasi mendapatkan predikat tidak sehat. Berdampak pada biaya yang dikeluarkan oleh koperasi.

5. Aspek Likuiditas Koperasi pada tahun 2015-2017 tidak mengalami perubahan dari tahun ketahun. Pada tahun 2015-2017 total skor 3,75 maka dapat diartikan kinerja keuangan koperasi mendapatkan predikat tidak sehat. Berdampak pada memenuhi kewajiban jangka pendek koperasi

6. Kinerja keuangan koperasi untuk lima aspek yang diteliti ternyata dari tahun 2015-2017 berada pada predikat dalam pengawasan berarti kurang sehat.

\section{DAFTAR PUSTAKA}

Arikunto, Suharsimi. 2014. Prosedur Penelitian Suatu Pendekatan Praktik. Jakarta: Renika Cipta

Anita Aprilia, "Nit4aprilia: Analisis Rasio Keuangan untuk Mengukur Kinerja Keuangan pada Koperasi Dhaya Harta Jombang,"dalam Ilmu dan Riset Manajemen, (Vol. 3 No. 2, 2014)

Dwi Putra Darmawan, "Globalnet41: Analisis Kinerja Keuangan pada Koperasi Serba Usaha di Kabupaten Buleleng" dalam Manajemen Agribisnis, (Vol. 1, No 2, Oktober 2013)

Hendrojogi. 2015. Koperasi: Asasasas, Teori, dan Praktik. Jakarta: PT. Raja Grafindo Persada

Harahap, Sofyan Syafri. 2010. Analisis Kritis atas Laporan Keuangan. Jakarta: PT. Raja Grafindo Persada

Ida Ayu Kade Mas Uttari Dewi, "lauttarid: Analisis Kinerja Keuangan Koperasi Serba Usaha di Kecamatan Buleleng Tahun 2013," dalam 
Manajemen, (Vol.3 Tahun 2015)

Kasmir. 2008. Analisis Laporan Keuangan. Jakarta: PT. Raja Grafindo Persada

Munawir. 2010. Analisa Laporan Keuangan. Yogyakarta: Liberty

Nazir, Moh. 2011. Metode Penelitian. Bogor: Galiah Indonesia.

Priyono. 2010. Manajemen Sumber Daya Manusia. Jakarta: Zifatama Publisher

Peraturan Deputi Bidang Pengawasan Kementerian Koperasi dan Usaha Kecil dan Menengah Republik Indonesia Nomor 06/Per/Dep.6/IV/2016 tentang Pedoman Penilaian Kesehatan Koperasi Simpan Pinjam dan Unit Simpan Pinjam Koperasi

Sugiyono. 2013. Metode Penelitian Bisnis. Bandung: Alfabeta

Rudianto. 2010. Akuntansi Koperasi. Jakarta, Edisi Kedua. Jakarta: Erlangga

Undang-undang Republik Indonesia Nomor 17 Tahun 2012. Tentang Perkoperasian 2012. Jakarta: Sinar Grapika 